\title{
Retail turnover clauses in an online world
}

\author{
J A Pretorius \\ C E Cloete \\ Department of Construction Economics \\ University of Pretoria, South Africa
}

\section{Keywords}

Turnover rental, online shopping, rental clauses, risk sharing

\begin{abstract}
Purpose of this paper: Traditionally, lessors and lessees of especially national tenants use a risksharing retail rental model, which consists of a fixed rental and a risk sharing component, the so-called turnover clause. In an online retail environment, however, revenue is generated through several channels and it is not possible to assign to each store a portion of the total revenue by simply looking at individual instore turnover. The opportunity of selling online provides disincentives to tenants to generate instore revenues, thereby increasing the risk of turnover-based contracts becoming ineffective. This article investigates whether the commonly used risk-sharing clause in retail rental agreements used in South Africa is still the most relevant in this changing environment. Four alternative rental constructs: (i) fixed rental only, (ii) turnover rental only (iii) geofenced rental and (iv) alternative performance metrics are investigated.

Methodology: Role players in the South African retail real estate are interviewed and questions formulated based on the results of the literature review are discussed on a one-on-one basis. The interviews are analysed and solutions to accommodate the disruptive effects of online retailing on the calculation of turnover rentals are tested against industry knowledge of the participants.

Findings: The preliminary finding is that the existing model will continue to be the preferred model for the foreseeable future because of the underlying adversarial relationship between retail lessors and lessees and the existing model's ability to share risk while guaranteeing a minimum fixed rental.
\end{abstract}

Corresponding author: C E Cloete

Email addresses for the corresponding author: chris.cloete@up.ac.za

First submission received: $5^{\text {th }}$ January 2020

Revised submission received: $12^{\text {th }}$ May 2020

Accepted: $10^{\text {th }}$ June 2020

\section{Introduction}

As online shopping in the retailing industry evolves, the distinction between bricks-and-mortar and online retailing is fading (Brynjolfsson, Hu and Rahman, 2013:1). Because of this blurring of roles, bricksand-mortar stores are becoming only one of a set of channels where retailers must simultaneously accommodate and anticipate consumer demand and meet varying lead times (Hubner, Holzapfel and Kuhn, 2016:257). It is a major misconception that internet sales are made primarily by online retailers. Research from the United States shows that pure online retailers account for less than $4 \%$ of all retail sales, while bricks-and-mortar retailers are investing heavily in online platforms to meet rising consumer demand for omnichannel shopping (CBRE, 2017:4). Within the South African context, a slower, but similar trend is observed (Groover, 2017:4). By the end of 2017, South African annual retail sales reached R 1 trillion (\$22 trillion), with online sales increasing to $1.8 \%$ of the total retail spend - up from 1.2\% in 2016 . This represented a 22\% annual increase since 2016 (Prinsloo, 2018:2).

Amid this digital innovation and growth in online retailing, traditional retail leasing and rental models have remained largely unaltered and as a result, retail real estate professionals in developed countries are beginning to re-evaluate the existing retail leasing models and rent metrics to question whether traditional approaches are still fit for purpose (O'Roarty and Billingse, 2015:4). In the current model, turnover rental is collected from stores and other retail operations within a shopping centre, on the assumption that sales can be attributed to a specific site and are easily audited (Williams, 2014:794). Thus, within the retail real estate industry, the most important economic underlying factor is represented by the 
amount of physical sales performed in a store (the turnover), and rent negotiation focuses on the level of sales achieved (trading density) by the retailer in a specific store (Gallosti, 2015:19).

In an online retail environment, revenue is generated through several channels (some non-trackable purchases) and it is not possible to assign to each store a portion of the total revenue by simply looking at individual instore turnover. The existing approach to turnover based calculations may therefore no longer be an efficient method to assess store trading performance. The opportunity of selling online provides disincentives to tenants to generate instore revenues, thereby increasing the risk of current turnover based contracts becoming ineffective (Gallosti, 2015:20-32). This study will form part of the first steps to formulate an appropriate online based turnover approach.

The current standard construct of the retail turnover clauses in the South African shopping centre environment makes provision for the sharing of risk through the inclusion of turnover rental. Turnover rent is calculated on a tenant's retail sales. Turnover rent is often assessed as an amount on top of the base rent. Once the store's sales reach the turnover threshold in a period, a fixed percentage will then be applied to the revenue.

This paper investigated whether South African retail role players agree that the realities of the growth of online retailing will necessitate a relook at the formulation of retail rental clause in retail lease agreements, and, if so, to what extent? Qualitative research was conducted with a sample of major role players within the South African retailing environment on approaches to online turnover rental capturing.

\section{Literature review}

Omnichannel retailing refers to the simultaneous use of a variety of distribution channels to interact and fulfil consumers' orders. Four alternative interaction patterns are identified for omnichannel retailing (Bell, Gallino and Moreno, 2014:47): (1) Traditional retail, where the consumer has a face-to-face interaction with the product and sales staff and departs the store with the product; (2) Shopping and delivery hybrid, where the consumer gathers information online, buys online and collect the item at the store ("click-and-collect"); (3) Online retail plus showrooms ("showrooming"), where the consumer can touch and feel the product at the store, the product is purchased at the store or online and then delivered to the consumer's home and (4) Pure-play eCommerce, where the consumer gathers information online, the product is ordered online and delivered directly to the consumer's home from a distribution centre or local store that acts as a fulfilment centre ("click-and-deliver").

Online channels complement rather than replace bricks-and-mortar channels (Herhause et al., 2015:319). Given the emerging complexities in capturing store rent in an online environment, the question arises if the traditional turnover calculation method is still effective in capturing the rental value of the store. A wider spectrum of approaches to capturing rental will potentially have to be used in future, with a possible range of approaches in selecting and devising rental models (O'Roarty and Billingse, 2015:3842).

In future successful retailers will have a presence in shopping centres either as a traditional store, a showroom or as a shopping-and-delivery hybrid. The bricks-and-mortar stores will remain important, allowing retailers to engage with consumers. (Wright, Lim, McCaster, Okino, Lee, Aguirre, Tanja, Pattaloong, Siow, and Simpson, 2017:24). Retailers are increasingly introducing click-and-collect, clickand-deliver and showrooming as strategic responses to online retailing but, although retailers continue to expand their stores, they are reducing their size requirements for them (Jones and Livingstone, 2015:235).

Historically, sharecropping was a form of turnover rental where a landowner permitted a tenant to use his land in return for either money, labour, or a share of the crops (Allen and Lueck, 1992:401). The modern origin of turnover rent agreements in retail dates to the Depression Era, during which many retailers went bankrupt due to high levels of fixed rent (Moussawi-Haidar and Çömez-Dolgan, 2017:912).

Currently, revenue sharing is an exception to other commercial real estate leasing transactions, which generally provide for a fixed rental payment independent of the tenant's business success and where lessors bear little, if any, of their tenant's business risk. This exception occurs almost universally in shopping centres, where retail tenants pay a percentage of their gross income as rent in addition to a minimum fixed base rent. (Wheaton, 2000:185). These retail leases do not merely involve rental contracts, but collaborative commitments by both parties to share gains and risks and jointly contribute to the proper functioning and promotion of the shopping centre and can be configured as a partnership or 
alliance between shopping centres and their tenants (Gomes, Paula and Macedo-Soares, 2017:172). Lessors and retailers are being challenged to better understand the value of store space, given that the traditional metric, turnover, will no longer necessarily be such an accurate representation of a location's productivity, as consumers increasingly use multiple touch points in their shopping journey and sales occur across channels. (O'Roarty and Billingse, 2015:31). Current turnover rent calculations typically include sales "made from the store," and exclude internet sales except for those "made from the store". Considering the various permutations involved in online shopping, defining what constitutes a sale being "made from the store", can be difficult (Jenny and West, 2013):

Items ordered instore online on behalf of a consumer by retail staff for delivery directly to the consumer's home because, for example, the item is out of stock or unavailable at the store.

Purchases made by the consumer instore online, to be delivered directly to the consumer's home.

Purchases made online on the retailer's website, to be picked up instore and fulfilled from the store's existing inventory; and

Purchases made online on the retailer's website, to be shipped directly to the consumer's home and fulfilled from the store's existing inventory without the consumer ever setting foot in the store.

Although online shopping is creating abundant opportunities for logistics firms and warehouse operators, it is irrefutable that it has disrupted the traditional retail model, calling into question whether turnover clauses can survive this market upheaval (Mason and Rawlence, 2017:21). The evolution of online retailing might increasingly place stress on the existing rental model, as retailers will have to determine the rent that a space justifies based on understanding the store's overall contribution to profitability in terms of both instore sales and the contribution of the store to online sales. Conversely, lessors do not have access to lessees' information regarding store contribution to non-store sales, which would help lessors assess the true value of a retail space (O'Roarty and Billingse, 2015:32).

By 2023 online shopping in SA will reach $\pm R 43$ billion ( $\pm \$ 95$ billion), which represents $3.3 \%$ of the total annual retail spend of R 1.3 trillion ( \pm R29 trillion) (Prinsloo, 2018:18-19). Historically, external factors influencing the store rent value included the shopping centre's return on investment, the centre's life cycle stage, locality, size and accessibility, the tenant's anchor status and externality generating abilities regardless of location (Duvenhage and Kruger, 2017:360). Internal factors influencing store rent value are controlled by either the tenant or the lessor, can benefit either one or both parties involved and include premiums for location prominence and convenience, accessibility to public transport accessibility, store size in relation to the centre, and the actual size of the store (Duvenhage and Kruger, 2017:361).

The growth of online retailing and retailers' digital platforms will eventually fundamentally change the traditional shopping centre store's rental value by empowering consumers and resulting in a much more complex consumer journey. The future retail store is one of several sales platforms through which the retailer can engage, entice, and transact with consumers. Achieving the sale in the most appropriate way is what matters and requires a dynamic approach to store rental composition, with the store as the cornerstone (O'Roarty and Billingse, 2015:35). Trends introduced in the store's rental rent determination by online retailing include click-and-collect, returns, showrooming, geofencing and the halo effect.

\section{Click-and-collect}

Defined as a sale that is transacted online and guaranteed to be in the store for consumer collection, click-and-collect sales are generally not deemed store turnover within the terms of a traditional lease agreement, although items that are reserved online and transacted instore normally are accounted for within the store. (O'Roarty and Billingse, 2015:35).

\section{Returns}

Generally, sales transacted online but returned to store is not reported as a subtraction instore turnover data (O'Roarty and Billingse, 2015:36). Returns typically generate additional sales with 23\% after instore returns when consumers returned items instore, either by click-and-collect or returns. Once in store, consumers are more likely to impulse buy or exchange the returned goods (Wright et al., 2017:24). The rate of return is also higher when consumers shop online, and the cost of these returns is much higher when returns are shipped back to a centralised distribution centre rather than returning to a store (Copra, 2015:142). 
Geofencing

Geofencing technology enables users to set electronic boundaries around physical locations, and to track the foot traffic going in and out of these boundaries (Carmodi, 2017). Retailers or shopping centre owners can keep track of a consumer's location in the shopping centre via the consumers' cellular telephone and send offers to them in real time when they are in the shopping centre or close to the retailer's store, to entice them into the shopping centre or store (Carmodi, 2017). Subsequently, increased customer visits to the store and conversion to sales can be achieved through tailored interactions that are more relevant to consumers. Retailers can create highly targeted offers which enables them to compete more efficiently, not only by setting perimeters around their own physical locations, but also by setting a geofence around their competitors' locations to intercept consumers with offers and promotions (Carmodi, 2017).

\section{The Halo effects}

The halo effect refers to the tendency for an impression created in one area to influence another, or how a store location can increase brand awareness for consumers, even those shopping exclusively online (O'Roarty and Billingse, 2015:36). One way to measure the halo effect within the retail environment is to measure the influence of physical stores on consumers and their brand awareness by examining the increase or decrease of web traffic and online sales. Latest research has found that the performance of retailers in the digital world is intricately linked to a presence or absence in physical stores (Brown, Busch, Chen, Muskin and Telsey., 2018:9-10).

Lessors should be able to protect themselves from the risks of online shopping by negotiating a share of revenue generated by online sales that have an interaction with the physical retail store (Mason and Rawlence, 2017:23). Approaches to capture rental value within an online environment can be summarised as follows:

\section{Fixed rent models}

This model bypasses the need to account for instore and online sales, but with a long-term risk of a lack of transparency once the existing lease gets reviewed (O'Roarty and Billingse, 2015:39).

\section{Conventional turnover models}

This model has a base rental accompanied by a variable income calculated as a percentage of sales achieved above a threshold (O'Roarty and Billingse, 2015:39). The inclusion of click-and-collect services and consumer orders through online instore terminals in the definition of the tenant's turnover at the premises is a prerequisite for this model (Mason and Rawlence, 2017:23).

Turnover rent only models without security of tenure

In this model the lessor retains the right to terminate the lease if a store consistently fails to reach an agreed sales target. Also referred to as "European Factory Outlet-Style Leasing Models" the value of the store's contribution to the retailer's wider online strategy (and equally the value of the retailer to the lessor's wider asset strategy) will be embedded implicitly in the rent (O'Roarty and Billingse, 2015:41);

\section{Geofenced turnover models}

Online sales are geo-coded and attributed to a shopping centre based on location in this model. Different turnover rates will have to be applied to different types of transactions, reflecting the variable contribution of the store (O'Roarty and Billingse, 2015:42). Consequently, lessors can negotiate a share of revenue generated by online sales within a specified geographical radius of the shopping centre, as seen in the Australian retail market (Mason and Rawlence, 2017:23); and

\section{Alternative performance metrics}

Based on information shared because of collaborative relationships between lessors and retailers, this model rewards lessors who have transformed shopping centres into places that attract, entice, and engage consumers by delivering on experience, convenience, and exceptional consumer service. These new performance metrics could include: Net shopping hours which measure both the volume of consumers and their dwell time, thereby providing a measure of the consumer opportunity afforded (O'Roarty and Billingse, 2015:44); Volume of agreed-target consumers where lessors and retailers agree 
upon the characteristics of a store's target consumer - their consumer-and agree on appropriate hurdle rates (Gallosti, 2015:39; O'Roarty and Billingse, 2015:44); and Conversion rates and basket size that link footfall, or potential consumer volume, to sales by measuring both the number of consumers that transact and the average basket size of transactions (Gallosti, 2015:45).

\section{Methodology}

Interviews were undertaken to obtain views prevalent in the South African retail real estate industry on the different approaches to capturing rental value within an online environment. These interviews were conducted through scheduled face-to-face sessions. The format was conversation-based with an interview guide used to facilitate the discussion to acquire as many insights as possible from participants (Gallosti,2015:36).

Initially the plan was to approach lawyers, retailers, and owners of shopping centres with the questionnaire to gain insights on the different approaches to capturing rental value within an online environment. Due to the adversarial relationship between landlords and tenants it quickly became apparent that retailers were not prepared to allow their staff members to give their views on capturing rental value within an online environment (of the five national retailers that were approached, only one agreed to a scheduled interview). This necessitated the identification of participants who had previously worked for national retailers and who also had knowledge of and experience in online trading. In addition, a retail researcher with 30-year retail experience was also identified and interviewed. During the interviews it became apparent that IFRS-16 accounting standards will play an important role in retail lease design and a specialist was identified for an interview. Contrary to the initial interview design it became quickly apparent that the legal drafting of capturing rental value within an online environment is not the core of the problem, but rather the inherent adversarial relationship between retailers and landlords.

The above selection resulted in a total of ten participants who were involved in leasing processes within an online trading environment. The participants had a combined experience of 124 years in the retail lease environment (Table 1).

Table 1: Characterisation of participants

\begin{tabular}{|c|c|c|c|}
\hline $\begin{array}{l}\text { Participant } \\
\text { number }\end{array}$ & Industry role player type & $\begin{array}{l}\text { Position and number of } \\
\text { years' experience in retail } \\
\text { lease negotiations }\end{array}$ & Contribution of participant \\
\hline 1 & $\begin{array}{l}\text { Listed Real Estate } \\
\text { Investment Trust } \\
\text { (Reit) }\end{array}$ & $\begin{array}{l}\text { National Leasing Manager } \\
12 \text { years total leasing } \\
\text { exposure, } 5 \text { years retail } \\
\text { lessee exposure }\end{array}$ & $\begin{array}{l}\text { In depth interview on } 15 \text { February } 2019 \\
\text { on the various approaches to capturing } \\
\text { online rental value }\end{array}$ \\
\hline 2 & $\begin{array}{l}\text { Listed Real Estate } \\
\text { Investment Trust } \\
\text { (Reit) }\end{array}$ & $\begin{array}{l}\text { Asset Manager } \\
15 \text { years exposure as lessor }\end{array}$ & $\begin{array}{l}\text { In depth interview on } 15 \text { February } 2019 \\
\text { on the various approaches to capturing } \\
\text { online rental value }\end{array}$ \\
\hline 3 & $\begin{array}{l}\text { National Property } \\
\text { Management Company } \\
\text { (Property Manager) }\end{array}$ & $\begin{array}{l}\text { Key Account Manager } \\
\text { (CAM) } \\
6 \text { years retail lessor } \\
\text { exposure, } 3 \text { years retail } \\
\text { lessee exposure }\end{array}$ & $\begin{array}{l}\text { In depth interview on } 22 \text { February } 2019 \\
\text { on the various approaches to capturing } \\
\text { online rental value }\end{array}$ \\
\hline 4 & $\begin{array}{l}\text { Listed Real Estate } \\
\text { Investment Trust } \\
\text { (Reit) }\end{array}$ & $\begin{array}{l}\text { Asset Manager } \\
19 \text { years retail industry } \\
\text { exposure as lessor }\end{array}$ & $\begin{array}{l}\text { In depth interview on } 26 \text { February } 2019 \\
\text { on the various approaches to capturing } \\
\text { online rental value }\end{array}$ \\
\hline 5 & $\begin{array}{l}\text { National Property } \\
\text { Management Company } \\
\text { (Property Manager) }\end{array}$ & $\begin{array}{l}\text { Key Account Manager } \\
(\mathrm{CAM}) \\
15 \text { years retail lessor } \\
\text { exposure }\end{array}$ & $\begin{array}{l}\text { In depth interview on } 27 \text { February } 2019 \\
\text { on the various approaches to capturing } \\
\text { online rental value }\end{array}$ \\
\hline
\end{tabular}




\begin{tabular}{|c|c|c|c|}
\hline 6 & $\begin{array}{l}\text { National Property } \\
\text { Development Company } \\
\text { and lessor of a portfolio of } \\
\text { retail properties }\end{array}$ & $\begin{array}{l}\text { Leasing Director } \\
10 \text { years retail lessor } \\
\text { exposure }\end{array}$ & $\begin{array}{l}\text { In depth interview on } 28 \text { February } 2019 \\
\text { on the various approaches to capturing } \\
\text { online rental value }\end{array}$ \\
\hline 7 & $\begin{array}{l}\text { National Property } \\
\text { Management Company } \\
\text { (Property Manager) }\end{array}$ & $\begin{array}{l}\text { Divisional Director } \\
\text { Research } \\
30 \text { years retail leasing } \\
\text { exposure }\end{array}$ & $\begin{array}{l}\text { In depth interview on } 8 \text { March } 2019 \text { on } \\
\text { the various approaches to capturing } \\
\text { online rental value }\end{array}$ \\
\hline 8 & $\begin{array}{l}\text { National Retailer with } \\
\text { additional African footprint }\end{array}$ & $\begin{array}{l}\text { Real Estate Director } \\
6 \text { years retail leasing } \\
\text { exposure }\end{array}$ & $\begin{array}{l}\text { In depth interview on } 13 \text { March } 2019 \text { on } \\
\text { the various approaches to capturing } \\
\text { online rental value }\end{array}$ \\
\hline 9 & $\begin{array}{l}\text { Listed Real Estate } \\
\text { Investment Trust }\end{array}$ & $\begin{array}{l}\text { Senior Financial Manager } \\
5 \text { years retail exposure }\end{array}$ & $\begin{array}{l}\text { In depth interview on } 15 \text { March } 2019 \text { on } \\
\text { the long-term implications of IFRS } 16 \\
\text { accounting standards for retail leasing }\end{array}$ \\
\hline 10 & $\begin{array}{l}\text { Commercial attorney } \\
\text { specialising in drafting of } \\
\text { lease agreements between } \\
\text { shopping centre lessors and } \\
\text { lessees }\end{array}$ & $\begin{array}{l}\text { Attorney } \\
6 \text { years drafting experience } \\
6 \text { years litigation experience }\end{array}$ & $\begin{array}{l}\text { In depth interview on } 18 \text { March } 2019 \text { on } \\
\text { the various approaches to drafting } \\
\text { turnover rental clauses within an online } \\
\text { environment }\end{array}$ \\
\hline
\end{tabular}

\section{Results}

\section{The future of online retailing in South Africa}

Online retailing has become a permanent feature of the South African retailing landscape and all 10 participants expect it to continue growing, albeit at a slower pace than in the developed world. Currently, it constitutes an exceedingly small portion of South Africa retailers' turnover. This confirms the research done by Prinsloo (2018). Responses also confirmed that online shopping complements, rather than replaces, brick-and-mortar stores (Herhause, 2015). Click-and-collect, showrooming and additional revenue generated by consumers returning goods to shopping centres are the main influences on online shopping for South African shopping centres (O'Roarty and Billingse, 2015). Online retailing will remain a reality within the South African retail market, but it will not replace traditional bricks-and-mortar stores.

\section{Traditional turnover calculation in an online world.}

Most participants confirmed that, where online sales are included in turnover calculations, the traditional method of calculating a base rent plus a percentage turnover rent is still being used to address online sales (Mason and Rawlence, 2017). It is apparent from the respondents' feedback that the various types of retailers disagree on the inclusion of online shopping in turnover rental. Participants working on the lessor side generally expressed a reluctance in decreasing the fixed portion of fixed rent and increasing the variable portion, while participants employed by the lessee side support an increase in variable rental and a reduction in fixed rental. These findings support the research of Gallosti (2015), who also found that the root of this reluctance is the financial constraints imposed by the valuation methodology used within the property sector and the resultant access to financing by lessors.

\section{Potential alternative approaches to turnover calculation in an online world.}

Fixed rent models.

While participants confirm that, in practice, most retailers fail to reach their breakpoints to pay turnover, the consensus is that risk-sharing still forms the basis of the relationship between shopping centre owners and retailers. Therefore, the introduction of turnover clauses as mentioned by MoussawiHaidar and Çömez-Dolgan (2017) remains valid today within South Africa.

Turnover rent only models without security of tenure

The participants agree that security of tenure is critical for the financial viability of most lessors' mortgage commitments. The variable income model is not currently an option within the South African 
context unless a major change in the method of financing shopping centres occurs. The feedback does not support the potential model as proposed by O'Roarty and Billingse (2015).

\section{Geofenced turnover models}

Although most of the participants express support for the philosophy behind geofenced turnover models as set out by Carmodi (2017), the consensus is that the current lack of technological infrastructure and the high cost of data in South Africa will impede the implementation of this model, especially in the lower income areas.

\section{Alternative performance metrics}

The current viability of the alternative performance metrics as proposed by O'Roarty and Billingse (2015) and Gallosti (2015) is generally disputed by the participants and does not seem to occur in South Africa. The research by Gallosti (2015), suggesting that a visitor-based contract can be used to form the basis of a rental agreement between lessors and lessees and that such an agreement could satisfy both parties, could not be confirmed.

\section{Future opportunities of consumer information sharing}

Participants agree that the current basis of the relationship between lessors and retailers is adversarial, with both parties trying to "win" during negotiations. Most participants do however agree that the sharing of consumer information will become critical in the future, confirming the research of Wulf and Butel (2017) that states that collaborative relationships are seen in the long term as a key capability which is essential for building competitive advantage.

\section{Recommendations}

Although the feedback from participants shows that the existing turnover rental construct will remain the most used for the foreseeable future, further studies on retail turnover clauses within an online environment should focus on the following questions:

Is it possible to change the current adversarial approach in retail lease negotiation to a collaboration approach?

It might be possible to introduce a more collaborative approach in the negotiation process if both parties could experience a higher return by engaging on a collaborative, rather than adversarial, basis. This would enable lessors and lessees to spend less time on maximising their own negotiation positions and more time on extracting the most value, whether income or property growth related. It would also enable the parties to share each other's consumer data to the benefit of both parties. Most of the participants in this study expressed a desire to have a more collaborative contractual relationship between lessors and lessees and this should be explored further.

Would an alternative performance metrics contract ever be viable as a substitute to the current preferred model of fixed and variable rental contracts?

The viability of the alternative performance metrics contracts could be tested with historical feet count, spend per head and shopping densities used on a comparative basis against actual turnover rental paid; and

Would the introduction Wi-Fi in shopping centres and the resultant ability to introduce geofencing around shopping centres strengthen the argument to include online shopping within geofenced areas in shopping centres' turnover calculations?

Wi-Fi is currently rolled out at several South African shopping centres. As the data collected on the use of Wi-Fi becomes available, it should be possible to measure and analyse the impact of the introduction of Wi-Fi services in shopping centres. The resultant increase in accuracy of current measurement of actual visits to a shopping centres, can lead to the development of a rental model that will enable lessors to geofence their shopping centres and share data with lessees within this geofenced area.

\section{Research limitations}

South African commercial law has its basis in English commercial law, but no reported case law involving turnover rental and online shopping could be found within English Law Reports or the South African Law Reports. Another limitation is the lack of access to real online sales data from retailers due to confidentiality concerns. In addition, where South African retailers (mainly stores) also have online sales, 
both store and online sales are captured together but purely online retailers are captured separately under "all other retailers", thus making it impossible to use the StatsSA Retail Trade Industry Report to ascertain the growth of online shopping in South Africa.

\section{Contribution and Practical implications}

Online selling may lead to the risk that traditional turnover-based contracts based upon the sales in a brick-and-mortar stores do not provide a fair and appropriate mechanism for profit-sharing between the lessor and the lessee. This paper contributes to the formulation of an appropriate risk sharing lease agreement between lessors and lessees within an online retail environment.

\section{Conclusions}

The increasing prevalence of online shopping provides new challenges for the drafting of leases that will result in an equitable allocation of profit between the lessor and the lessee. While traditional retail leases incorporating turnover clauses are based upon the measurement of turnover in the store itself, some or even most of the sales may occur online in an online environment.

Although it is expected that existing turnover rental agreements will remain the most used for the foreseeable future, a desire was also expressed to have a more collaborative contractual relationship between lessors and lessees instead of the present adversarial relationship.

\section{References}

Allen, D. and Lueck, D., 1992, 'Contract Choice in Modern Agriculture: Cash Rent Versus Cropshare,' The Journal of Law and Economics, 35(2), pp. 397-426. Doi: 10.1086/467260.

Bell, D. R., Gallino, S. and Moreno, A., 2014, 'How to win in an omnichannel world', MIT Sloan Management Review, 56, 45-53.

Brown, A.T., Busch, D.J., Chen, O., and Muskin S. and Telsey, D., 2018, 'The Halo Effect: How Bricks Impact Clicks', International Council of Shopping Centres.

Brynjolfsson, E., Hu, Y. J. and Rahman, M. S., 2013, 'Competing in the age of omnichannel retailing', MIT Sloan Management Review, 54, 1-7.

Carmody, B., 2017, 4 Ways Geofencing Helps Physical Retailers Compete with Online Shopping, viewed on 17 March 2019 from https://www.inc.com/bill-carmody/4-ways-geofencing-helps-physical-retailers-complete-with-onlineshopping.html.

CBRE., 2017, U.S. Retail Trends Beyond the Headlines: Is the E-pocalypse Here?, viewed 18 January 2018, from https://www.cbre.com/research-and-reports/US-Retail-Beyond-the-Headlines-August-2017.

Duvenhage, A. and Kruger, A., 2017, 'Retail Format Selection: Occupancy Cost and Profitability', Journal of Economic and Financial Sciences, 10(2), pp. 356-375.

Gallosti, L., 2015, 'Optimization of Commercial Retail Leases-A New Model'. Master of Science, KTH Architecture and Built Environment, Stockholm.

Gomes, R.M. de A.B., Paula, F.de O. and Macedo-Soares, T.D.L. van A., 2017, 'Strategic Aalliances of Shopping Centers in Brazil: Network Perspective', Management Research, vol. 15, no. 2, pp. 167-186. Doi 10.1108/MRJIAM-04-2016-0661.

Groover, J., 2017, Online Conundrum. Shopping SA. 167 ed, South African Council of Shopping Centres.

Huibner, A., Holzapfel, A. and Kuhn, H., 2016, 'Distribution systems in omnichannel retailing', Business Research, 9, 255-296. doi: 10.1007/s40685-016-0034-7.

Jenny, C.A., and West, R.W, 2013 Effect of E-Commerce on Percentage Rent viewed 17 February 2019 from https://www.vonbriesen.com/legal-news/2231/effect-of-e-commerce-on-percentage-rent.

Jones, C. and Livingstone, N., 2015, 'Emerging implications of online retailing for real estate', Journal of Corporate Real Estate, 17, pp. 226-239.

Kruger, L. F., 2016, 'The determination and disclosure of the contribution of turnover rent to lessor revenue in the South African retail property sector', Master of Philosophy, University of South Africa.

Mason, K. and Rawlence, D., 2017, 'Game over for the turnover lease?', RICS Property Journal, May/June 2017, pp.2223.

Moussawi-Haidar, L. and Çömez-Dolgan, N., 2017, 'Percentage Rent Contracts between Co-Stores', European Journal of Operational Research, 258(3), pp. 912-925. doi: 10.1016/j.ejor.2016.08.063.

Naidoo, K., 2019, e-mail, 15 February, keshneen@statssa.gov.za

O'Roarty, B. and Billingse, A., 2015, 'Exploring new leasing models in an omnichannel world', New York: International Council of Shopping Centres. 
Prinsloo, D.A., 2018, 'Online Shopping Steady Increasing but still far behind', Report by the South African Council of Shopping Centres pp.1-19.

Rawlence D., 2019, e-mail, 6 March, drawlence@boodlehatfield.com

Wheaton, W. C., 2000, 'Percentage Rent in Retail Leasing: The Alignment of Landlord-Tenant Interests', Real Estate Economics, 28(2), pp. 185-204.

Williams, J., 2014, 'Percentage Rents with Agency', Real Estate Economics, 42, 791-828. doi: 10.1111/1540-6229.12038.

Wright, K., Lim, M., McCaster, G., Okino, T., Lee, E., Aguirre, R.J., Tanja, J., Pattaloong, N.N., Siow, E. and Simpson, A., 2017, UBS Evidence Lab: How is the clicks 'n bricks revolution re-shaping shopping centres?, UBS Securities Asia Limited, viewed on 23 June 2017, from http://ubs.com/investmentsresearch.

Wulf, A. and Butel, L., 2017 'Knowledge Sharing and Collaborative Relationships in Business Ecosystems and Networks', Industrial Management and Data Systems, 177(7), pp. 1407-1425. Doi: 1108/IMDS-09-2016-0408. 